\title{
Influence of climatic warming on the amount of snow cover and water quality of Lake Biwa, Japan
}

\author{
Hiroji Fushimi \\ Lake Biwa Research Institute, Otsu, Shiga 520, Japan
}

\begin{abstract}
The amount of snow cover in the Lake Biwa catchment area has changed significantly from $1.9 \times 10^{12} \mathrm{~kg}$ in 1974 to $0.3 \times 10^{12} \mathrm{~kg}$ in 1979. The amount of snow cover was less in the warmer winter and when the amount of snow cover was less than $10^{12} \mathrm{~kg}$, the average amount of snow cover in recent years, the lowest dissolved-oxygen concentration in the deep layer rapidly decreases. Climatic warming will significantly decrease the amount of snow cover in Lake Biwa catchment area and the dissolved-oxygen concentration in the deep layer of the lake, which may further enhance eutrophication of the lake.
\end{abstract}

\section{INTRODUCTION}

Lake Biwa, the largest lake and the most important freshwater resource in Japan, is located in Shiga Prefecture of Kinki district in central Japan. Some 13 million people in Osaka, Kyoto and several other municipalities depend on the water supply from Lake Biwa and its outflowing Yodo River.

The areas of Lake Biwa and its catchment area are 674 and $3174 \mathrm{~km}^{2}$, respectively. The Lake Biwa catchment area is surrounded by mountain ranges of a little more than $1000 \mathrm{~m}$ a.s.l. The vast winter snow cover in the northern part of the catchment area is a very important water resource for Lake Biwa.

The water from melted snow has a high concentration of dissolved oxygen. In years when the amount of snow cover is meager, dissolved-oxygen concentration becomes significantly low in the deep layer, or hypolimnion, of the lake. This indicates that snow cover plays an important role in sustaining the dissolved-oxygen concentration and maintaining the water quality of Lake Biwa.

It is reported that annual average air temperature will increase by $1.5^{\circ}-3.5^{\circ} \mathrm{C}$ in Japan by the 2030 s (Japan Meteorological Agency, 1989), while Tegart and others (1990) estimate a rise of global average air temperature by $1.5^{\circ}-4.5^{\circ} \mathrm{C}$ between 2025 and 2050 when the $\mathrm{CO}_{2}$ concentration will be double. Presuming this to be the case, we here investigate what will happen to the amount of snow cover in the Lake Biwa catchment area and the dissolved-oxygen concentration of Lake Biwa.

\section{AMOUNT OF SNOW COVER}

The amount of snow cover is defined in this paper as the total precipitation in the form of snow in the Lake Biwa catchment area (Fushimi, 1983).

Figure 1 indicates, from 1968 to 1983, annual

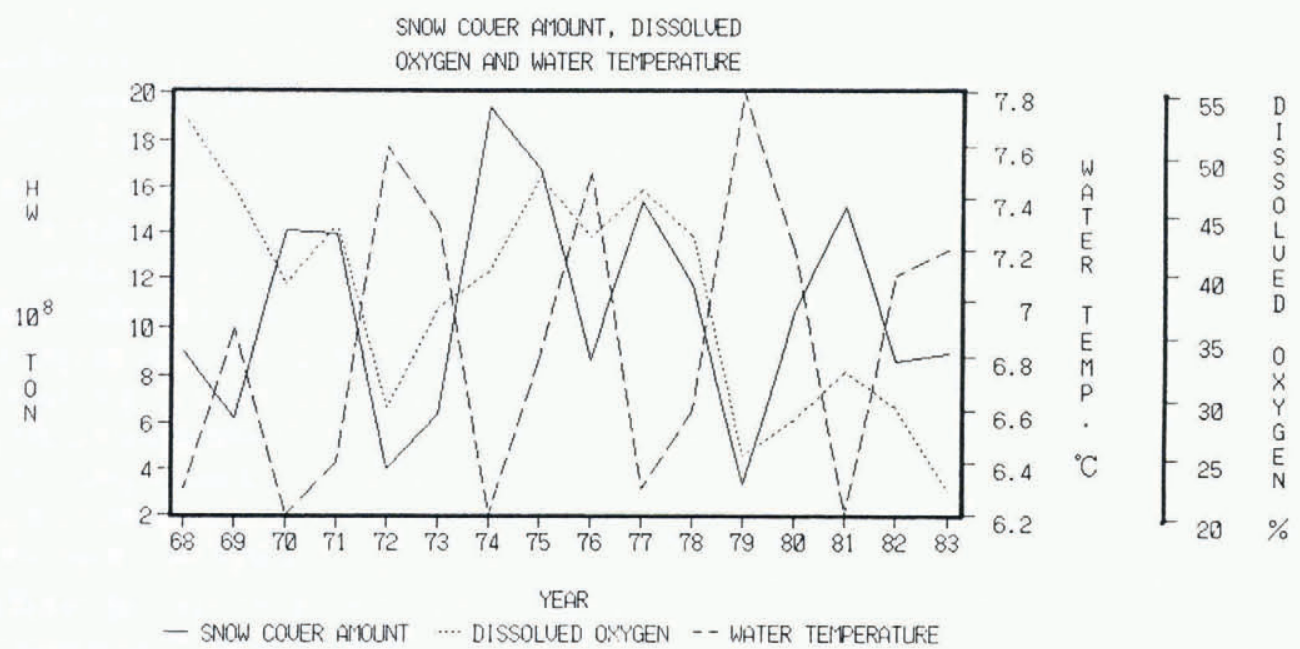

Fig. 1. Amount of snow cover in the Lake Biwa catchment area, lowest dissolved-oxygen concentration, and minimum water temperature of the deep layer of Lake Biwa. HW: amount of snow cover. 
variation in the amount of snow cover, the lowest dissolved-oxygen concentration just before the overturning period in the beginning of winter (as a per cent of saturation), and the minimum water temperature of the deep layer of the central part of Lake Biwa at the end of winter season (Fushimi, 1991).

The amount of snow cover in the Lake Biwa catchment area fluctuates from $0.3 \times 10^{12} \mathrm{~kg}$ in 1979 to $1.9 \times 10^{12} \mathrm{~kg}$ in 1974 with a mean of $1.03 \times 10^{12} \mathrm{~kg}$. When the amount of snow cover is above the mean, a lower water temperature and higher dissolved-oxygen concentration are observed. This is caused by the density current of melted snow subsiding from the river mouth into the deep layer of Lake Biwa. The amount of snow cover affects the dissolved-oxygen concentration, the water temperature and the eutrophication process in Lake Biwa.

Figure 2 shows the relationship between the amount of snow cover and the average winter air temperature from December to March at Hikone in the central part of the Lake Biwa catchment area. The amount of snow cover is less in a warmer winter but greater in a colder winter. The amount of snow cover decreases by $0.48 \times 10^{12} \mathrm{~kg}$ with an increase of $1^{\circ} \mathrm{C}$ in the average winter air temperature. Therefore, there is strong possibility that climatic warming will significantly reduce the amount of snow cover. However, the decrease in the amount of snow cover must be considered in relation to a concomitant increase of preciptiation and rise of snowline altitude in response to climatic warming.

\section{DISSOLVED-OXYGEN CONCENTRATION}

The depletion of dissolved-oxygen concentration in the deep layer of Lake Biwa was first reported by Naka (1973). Since then, similar results have been observed by

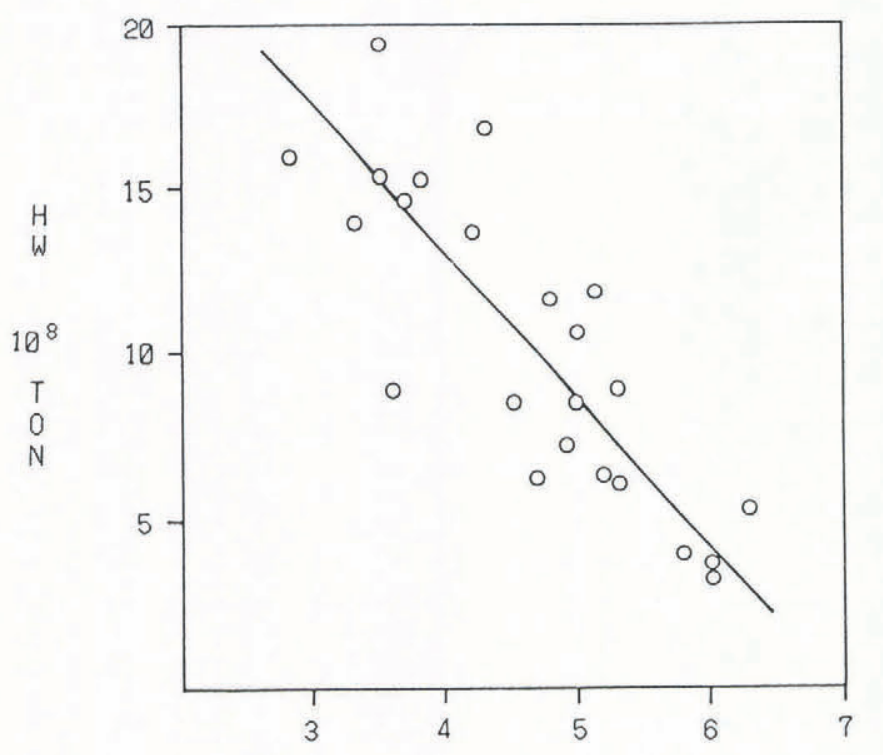

AU. WINTER TEMP. ${ }^{\circ} \mathrm{C}$

Fig. 2. Relationship between snow-cover amount and average winter air temperature. $H W$ : amount of snow cover.

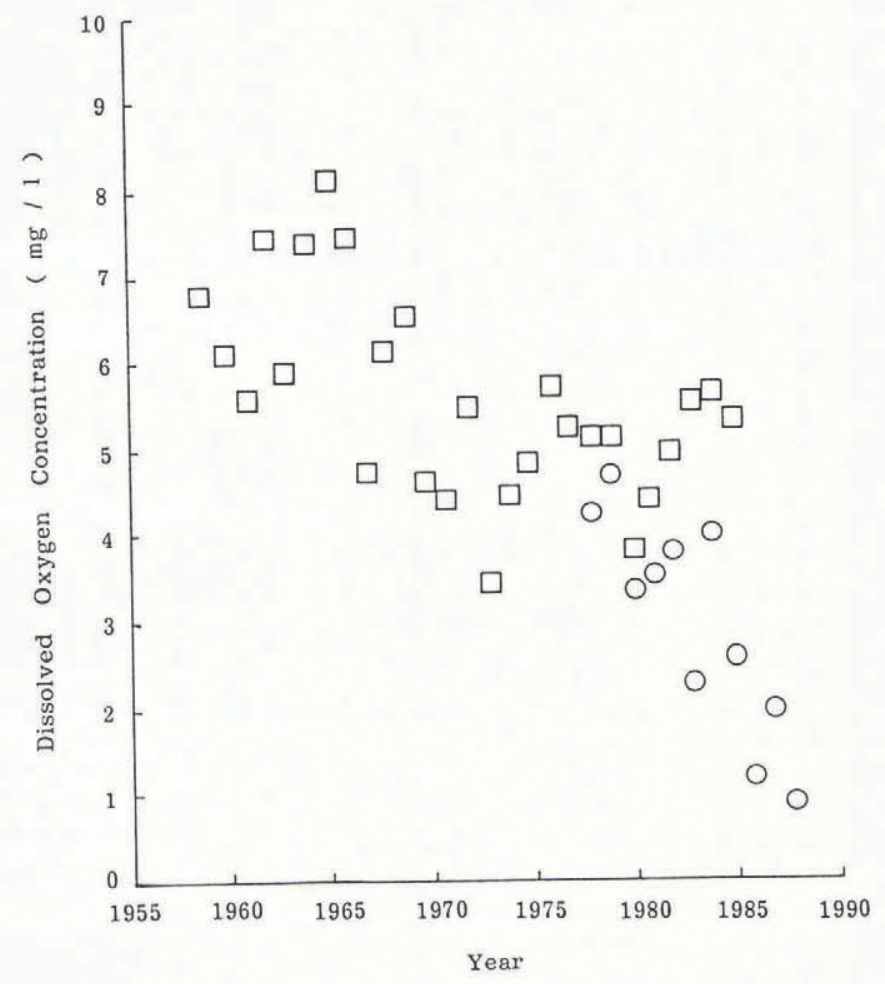

Fig. 3. Lowest yearly dissolved-oxygen concentration over a $35 y$ period in a hypolimnion of Lake Biwa. Squares indicate data observed by Shiga Prefectural Fisheries Experimental Station and circles that observed by Shiga Prefectural Institute of Public Health and Environmental Science.

the Shiga Prefectural Institute of Public Health and Environmental Science. Okuda and others (1987) and Kumagai (1988) found that the depletion of dissolved oxygen is caused not only by eutrophication, but also by the decrease of snow cover.

Figure 3 shows the yearly lowest dissolved-oxygen concentration measured in the deep layer of Lake Biwa from 1958 to 1988 . The measurement, made by Shiga Prefectural Fisheries Experimental Station and Shiga Prefectural Institute of Public Health and Environmental Science, was taken at the depth of $\sim 80 \mathrm{~m}$ in October and November, just before the overturning period when the concentration of dissolved oxygen in the deep layer reaches its minimum (Kumagai and Fushimi, in press).

Lake Biwa has suffered from eutrophication since the 1960 s and the dissolved-oxygen concentration in the deep layer of Lake Biwa has gradually decreased. If this decrease of the dissolved-oxygen concentration continues, anoxic conditions may prevail by the end of this century, allowing release of ammonia and phosphates, etc., from the lake-bottom sediments. Therefore, it is important to halt the lowering of the dissolved-oxygen concentration.

Figure 4 shows the relationship between the amounts of snow cover and the lowest dissolved-oxygen concentrations. When the amount of snow cover is less than $10^{12} \mathrm{~kg}$, the dissolved-oxygen concentration in the deep layer of Lake Biwa rapidly decreases. However, when the amount of snow cover is greater than $10^{12} \mathrm{~kg}$, the dissolved-oxygen concentration remains high. This means that a critical amount of snow cover of approximately $10^{12} \mathrm{~kg}$, the average amount of snow cover in recent years, is necessary 


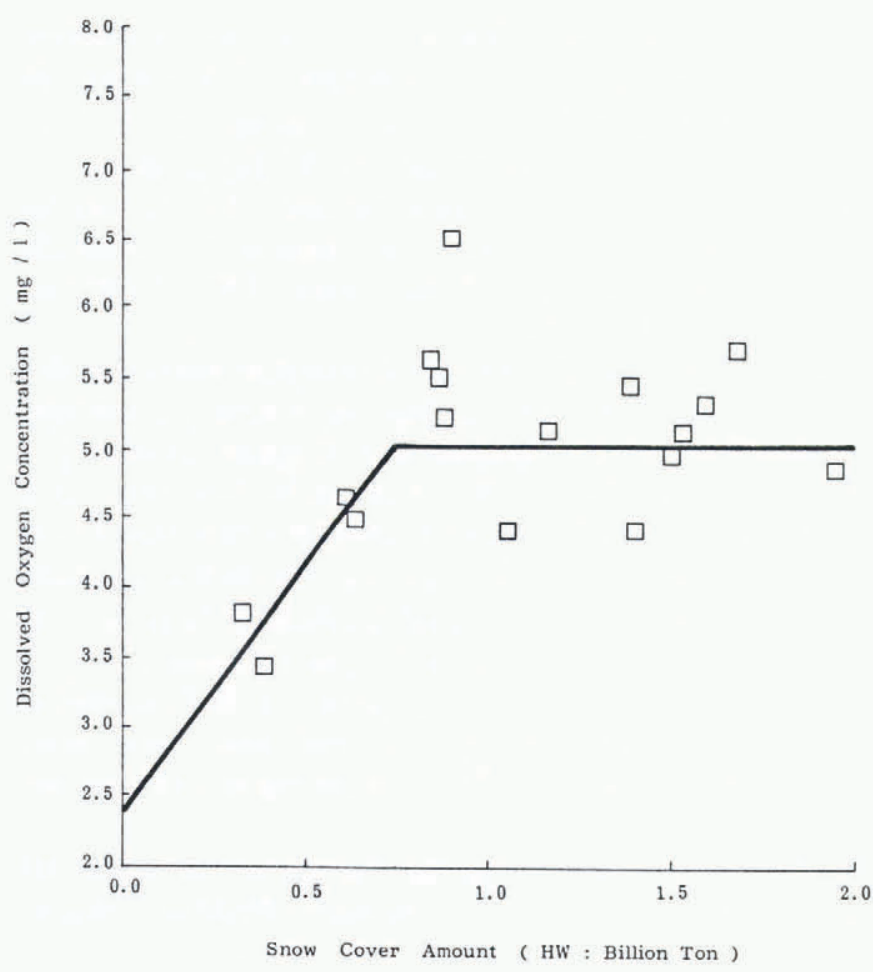

Fig. 4. Relatonship between snow-cover amount and the lowest dissolved-oxygen concentration.

to sustain the dissolved-oxygen concentration in the deep layer of Lake Biwa.

\section{DISGUSSION}

Figure 5 shows an average altitudinal distribution of snow-cover amounts up to $1400 \mathrm{~m}$ a.s.l. in the Lake Biwa catchment area. The solid line represents present-day conditions and the other curves show times of climatic warming with increase of precipitation of $10 \%, 20 \%$, $30 \%, 40 \%$ and $50 \%$ (Fushimi, 1991). There is a possibility that the amount of water vapor in the atmosphere will increase with climatic warming.

AUERAGE. HN DISTRIBUTION

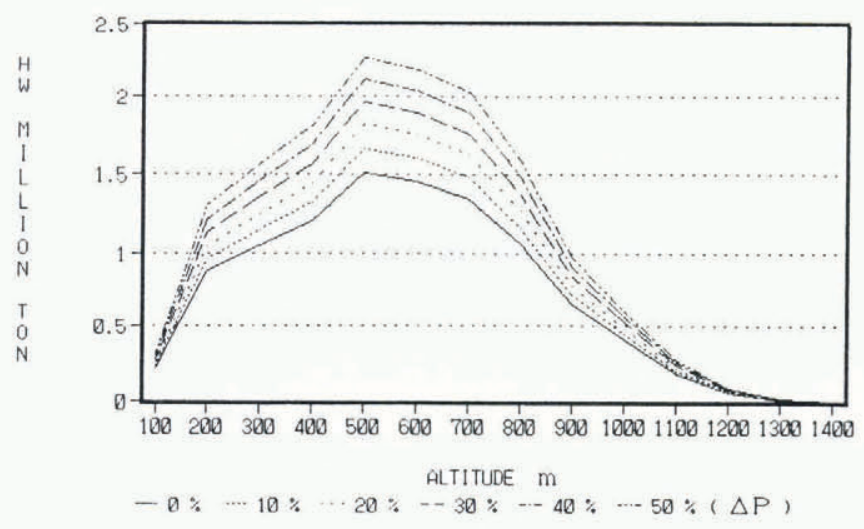

Fig. 5. Average altitudinal distribution of snow-cover amount in the Lake Biwa catchement area and possible increases due to hypothesized increases in precipitation. $H W$ : amount of snow cover.
Due to topographic conditions, the greatest amount of snow cover is stored at altitudes $400-800 \mathrm{~m}$ a.s.l. With climatic warming, the possibility of precipitation will increase and, at the same time, the altitude of the average snowline will rise. That is, the boundary altitude between rain and snow will be raised by climatic warming and the rise in snowline altitude will decrease the amount of snow cover. The amount of snow cover at the time of climatic warming must be estimated based on the variations in the amount of precipitation and the altitude of the average snowline.

Since a rise in the average snowline altitude is estimated by a temperature lapse rate of $0.67^{\circ} \mathrm{C} 100 \mathrm{~m}^{-1}$ in the Lake Biwa catchment area, the amount of snow cover is estimated to be zero at an area below the snowline altitude when the climatic warming proceeds. On the contrary, there will possibly be more snow cover at higher altitude due to an increase in precipitation. Therefore, the total amount of snow cover at higher altitude is calculated by the average altitudinal distributions of snow cover reflecting increases in precipitation of $10 \%, 20 \%, 30 \%, 40 \%$ and $50 \%$ (Fig. 5 ).

Figure 6 shows the amount of snow cover estimated in relation to the increase in precipitation in the $y$-axis (\%) and that of the average air temperature in the $x$-axis $\left({ }^{\circ} \mathrm{C}\right)$ under conditions of climatic warming. The shaded part shows that the amount of snow cover is less than $10^{12} \mathrm{~kg}$, or an approximate average in recent years, and the unshaded part greater than $10^{12} \mathrm{~kg}$.

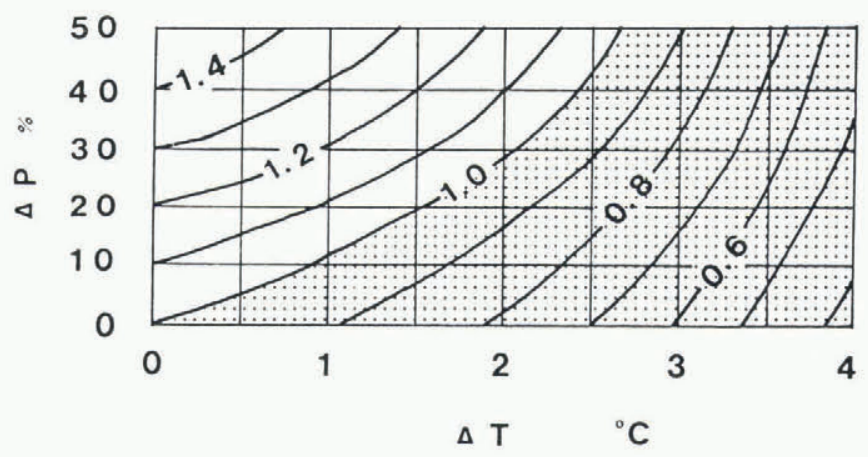

Fig. 6. Amount of snow cover estimated from an increase of precipitation (\%) and average air temperature $\left({ }^{\circ} \mathrm{C}\right)$. The amount of snow cover is indicated by a unit of $10^{12} \mathrm{~kg}$.

It is reported that an average air temperature will increase by $1.5^{\circ}-3.5^{\circ} \mathrm{C}$ by the $2030 \mathrm{~s}$. If the average air temperature increases by $1.5^{\circ} \mathrm{C}$, the amount of snow cover would not be more than $10^{12} \mathrm{~kg}$, unless the amount of precipitation is more than $20 \%$ in excess. If the average air temperature rises by $3.5^{\circ} \mathrm{C}$, the amount of snow cover would decrease significantly to about 0.6 and $0.7 \times 10^{12} \mathrm{~kg}$, even if the precipitation is, respectively, $20 \%$ and $40 \%$ in excess.

Since the inclinations of the snow-cover isogram curves become steeper when the average air temperature rises more than $3^{\circ} \mathrm{C}$, the more climatic warming proceeds, the less the amount of snow cover is. This is due to the topographic conditions in which the area $400-800 \mathrm{~m}$ a.s.l., where a large amount of snow cover in Lake Biwa catchment area is usually stored, becomes lower than the 
average altitude of the snowline under climatic warming.

Consequently, climatic warming could significantly decrease the amount of snow cover in the Lake Biwa catchment area and the dissolved-oxygen concentration in the deep layer of the lake, which may further enhance eutrophication of Lake Biwa. From the viewpoints of water quantity as well as water quality, we will face a difficult time making rational use of the water resources of Lake Biwa in the 21st century with predicted climatic warming.

\section{REFERENCES}

Fushimi, H. 1983. Snow cover in Lake Biwa catchment area. Bulletin of Lake Biwa Research Institute 2, 79-117. [In Japanese.]

Fushimi, H. 1991. Water circulation of Lake Biwa. Otsu, Lake Biwa Research Institute. [In Japanese.]

Japan Meteorological Agency. 1989. Report of unusual weather '89. Tokyo, Japan Meterological Agency. [In Japanese.]
Kumagai, M. 1988. Transport and sedimentation mechanism of suspended materials in Lake Biwa. In Okuda, S., ed. The front of disaster geomorphology, 123138. Kobe, Koyu Publishing Co. [In Japanese.]

Kumagai, M. and $\mathrm{H}$. Fushimi. In press. Inflows due to snow melt. In Imberger, J., ed. Physics in Lake Biwa, the largest lake in Japan. Washington, DC, American Geophysical Union.

Naka, K. 1973. Secular variation of oxygen change in the deep water of Lake Biwa. Japanese Journal of Limnology, 34(1), 41-43. [In Japanese with English summary.]

Okuda, S., K. Okunishi, R. Yoshioka, K. Yokoyama and T. Saito. 1987. Discharge from snowy mountains in a warm region. In Kira, T., ed. Preservation of water resources - problems on Lake Biwa drainage basin, Kyoto, Jinmon Publishing Co., 48-68. [In Japanese.]

Tegart, W.J. McG., G. W. Shaeldon and D. C. Griffiths, eds. 1990. Climate change, the IPCC impact assessment. Canberra, Australian Government Publishing Service.

The accuracy of references in the text and in this list is the responsibility of the author, to whom queries should be addressed. 